Centre for Evidence Based Medicine, Nuffield Department of Primary Care Health Sciences, University of Oxford, Oxford

Twitter @JKAronson Cite this as: BMJ 2022;376:0437 http://dx.doi.org/10.1136/bmj.0437 Published: 18 February 2022

\title{
When I use a word .... Medical patronymics, metronymics, and papponymics
}

Many family names are patronymics, surnames derived from fathers' first names, or more generally from those of some forebears. Metronymics, or matronymics, are similarly derived, but from the first name of a mother, and papponymics from the name of a grandfather. Different languages have different forms that denote patronymics. Typical patronymics are either derived directly from a given name (e.g. Andrews, Evans, Jones, Williams) or by adding a suffix, such as -son and variants or -ovich and variants, or a prefix, such as Mac, Mc, and $M^{\prime}$ (Scottish and Irish), $A p$ (Welsh), Fitz (English and Irish, from Norman French), and Ben or Bar (lewish). $O^{\prime}$ denotes an Irish papponymic. There are many medical examples of all of these.

Jeffrey K Aronson

\section{Family names}

Have you ever wondered what your surname means? The chances are that it's derived from a nickname, an occupation, or a place. Or, like mine, it's a patronymic.

As I discussed last week, ${ }^{1}$ the word patronymic comes

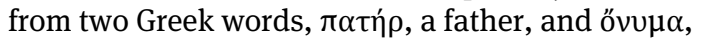
a name; in Hellenistic Greek the two were combined into a single word, $\pi \alpha \tau \rho \omega \dot{v} v \mu \circ \varsigma$, with the adjectival

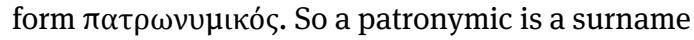
that is derived from the first name of your father, or more generally from that of a male forebear. A metronymic or matronymic is similarly derived, but from the name of your mother or a female forebear (Greek $\mu$ in $\imath \rho$, a mother; Hellenistic Greek $\mu \eta \tau \rho \omega v v \mu$ เкó $\varsigma$ ). A name derived from that of a

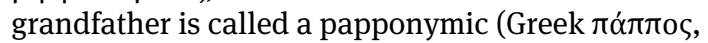
a grandfather).

Very occasionally a name comes from a more general term for a relative. One such is Cushing, of the disease and syndrome, from "cousin," which originally meant any relative or kinsman.

\section{Patronymics, metronymics, and papponymics}

In its simplest form, a patronymic surname is merely the ancestor's first name itself or some simple derivative. In some places, for example Tajikistan, people are called by their first name followed by their father's first name, a true patronymic; in Hungary the order is reversed. Elsewhere, the original first name of an ancestor has become a family name, handed down from generation to generation. For example, families descended from someone called Paul may have a surname such as Paul, Powell, or Pauli. Another simple way of using a first name as a surname is to add a possessive, such as $-s$ (as in the English and Welsh names Andrews, Evans, Jones, and Williams), -ing (as in the German names Benning and Janning), and - escu (as in the Rumanian names Ceaucescu and Ionesco).

Medical examples of this type of patronymic, of which there are many, include Albright's syndrome (Albert), Bartter's syndrome (Bertram), Benedict's solution, Franklin's disease, Gilbert's syndrome, Howell-Jolly bodies (Hywel), the angle of Louis, Ludwig's angina, and Tietze's syndrome (Terry).

There are several metronymic Jewish names, such as Baskin (after Basya), Dworkin (Deborah, Hebrew D'vora), Rifkin or Rifkind (Rifka), and Süsskind (Ziska); in each of these the suffix -kin or -kind is from the German word kind, a child. Some patronymics also end in -kin; Raskin, for example, is from a short version of Erasmus.

\section{The suffix -son and variants}

A common patronymic in English speaking, Scandinavian, and Teutonic countries is the suffix -son, spelt -sen in Denmark, Norway, and the Netherlands, and -sohn in Germany. In most countries once a surname of this type is established it persists through the family line and becomes a hereditary surname rather than a true patronymic. For example, if Peter, son of John came to be called Peter Johnson, Peter's son Timothy would not be called Timothy Peterson, but rather Timothy Johnson. However, in Iceland the true patronymic is still used. If Leifur has a son Eirik he is called Eirik Leifsson, but Eirik's son Harald is called Harald Eiriksson and so on. Daughters are also called after their fathers, but with the suffix -dottir instead of -son (for example Gudrun Haraldsdottir), and women retain their surname after marriage. Icelanders are called by their first name or by their first name plus the patronymic, never by the patronymic alone.

The many medical examples of this type of patronymic include Addison's disease (from Adam), Andersen's disease (Andrew),

Waterhouse-Friderichsen syndrome, Hansen's disease (Johannes), Jacksonian epilepsy, Mendelson's syndrome, Nelson's syndrome (Neil), Thomsen's disease, and Wilson's disease. Parkinson of the disease is a double patronym, since Parkin comes from Peterkin. Stevens-Johnson syndrome is two patronymics in one syndrome.

\section{The suffix -ovich and variants}

These indicate "son of" in Slavonic languages; the feminine form is -ovna. Russian names are complex, with a first name, a patronymic, and a surname. The 
author we know as Leo Tolstoy was properly called Lev Nikolaevich Tolstoy. Struggling to understand the dramatis personae in a Russian novel can be quite hard going for Western readers, because the characters are often called by several different names: the surname, the first name plus the surname, the first name plus the patronymic, or a diminutive pet name (such as Kolya, from Nikolai); furthermore, the patronymic can be shortened (for example, from Ivanovich to Ivanich). Take the famous mathematician, Nikolai Ivanovich Lobachevsky, satirized in a song by Tom Lehrer; he might be called Nikolai, Nikolai Ivanovich, Nikolai Lobachevsky, Kolya, or Kolya Ivanich.

There are different forms of this patronymic in other tongues, such as -owicz (Polish) and -ović (Croatian), and similar derivatives in non-Slavonic languages, such as -weit in German.

Medical instances include Wladislaus Onufrowicz, who gave his name to the Onuf nucleus in the ventral spinal horn at S2, Casimir Filipovich, whose sign is yellow discoloration of the palms and soles in typhoid, and Eli Moschowitz (from Moses), whose syndrome is better known as thrombotic thrombocytopenic purpura.

Sometimes the -ovich form is shortened to -ov or -ich. Thus, Korotkov of the sounds got his name from someone called Kortoyga (Russian for "Shorty"), Korsakov of the psychosis from a Korsak ("Foxy"), and Pavlov of the conditioned reflex from a Paul. And Ivan Illich, author of the famous diatribe Medical Nemesis and inventor of the concept of medicalisation, was probably descended from someone called Ilya (Elias).

The Russian word for an old woman is baba, which gives the metronymic Babich. Babinski, of the reflex, is formed from Babich plus -inski, a common Slavonic suffix that denotes a place. So the original Babinski was born in the place where an old woman (perhaps his mother or grandmother) lived.

\section{The prefixes $M a c, M c$, and $M^{\prime}$}

These are Scots and Irish patronymics, as in MacWilliam, McDonald, and M'Callum. Mac is sometimes prefixed to other words to indicate Scottish origin; for example, BBC Scotland has occasionally been called MacBeeb. When Ray Kroc founded the McDonald Hamburger company he called his main product Big Mac and later introduced other Mc derivatives, such as McNuggets and McMuffin; this in turn has led to the pejorative use of the prefix $M c$ to describe something that you think is cheap and nasty, such as McWar, applied to the burger war, which was defined in The Independent in 1991 as "a fast, cheap, well-packed conflict that makes you feel good and doesn't cause indigestion.” The introduction of Macintosh computers (Mac an Taoiseach, Gaelic,=son of the chief) led to other uses of Mac, including the names for pieces of software such as MacWrite and MacPaint.

In the Isle of Man, names that once began with Mac have been shortened to begin with C, K, or Q. For example, the Manx name Qualtrough is a shortened form of MacWalter.

Medical Macs include McArdle's disease, McBurney's point, McCarthy's reflexes, and McGoon's technique. The M'Naghten rules govern criminal responsibility in mental illness. And the Milroy of Milroy's disease is a corruption of McIlroy, from Mac Giolla Rua (Irish Gaelic), son of a red haired boy.

\section{The prefix $0^{\prime}$}

This is an Irish patronymic, or more precisely a papponymic, standing for grandson or descendant of, as in O'Brien, O'Connell, and O'Murphy. Medical examples include O’Beirne's sphincter, O’Dwyer's tube, and O’Hara's forceps.

\section{The prefix Ap and variants}

This is a Welsh patronymic, son of, as in Price (ap Rhys), Probert (ap Robert), and Pugh (ap Huw); Bowen (ap Owen) and Beddoes (ap Meredith); and Upjohn and Uprichard.

The Price-Jones curve is a distribution curve of erythrocyte diameters and Bowen's disease is intraepidermal carcinoma.

\section{The prefix Fitz}

The bastard sons of English and Irish nobles have sometimes been given this patronymic, from the Norman French, reflected in the modern French word fils, a son (Latin filius). Thus, Fitzgerald, Fitzherbert, Fitzroy, Fitzwilliam. Some Italian patronymics begin with $F i$ and some Hungarian ones end with it. But the Hungarian suffix comes from fia, meaning son of, which has nothing to do with filius; the Finno-Ugric languages are not Indo-European.

Medical Fitzes include Fitzgerald-Gardner syndrome (congenital polyposis coli) and Fitzhugh-Curtis syndrome (gonococcal peritonitis). Fibonacci, whose numbers are found in many natural phenomena, comes from the nickname Bonacci, meaning an excessively pious or hypocritical person. The name of the pharmaceutical company Sanofi means son of Alexander.

\section{The prefixes Ben and Bar, Bin and $I b n$}

Ben and Bar are Hebrew and Aramaic patronymics, son of, and I discussed some medical examples last week, including the Benjamin syndrome, St Bartholomew's Hospital, and Baruj Benacerraf.

Bin and Ibn are Arabic equivalents of Ben. In many Arab countries names are formed from the individual's first name, followed by the father's name, followed by the family (tribal) name; sometimes the grandfather's name is also inserted. The "son of" form can also be included, as in Osama bin Laden.

\section{Conclusions}

This is just a brief review of some common patronymics, metronymics, and papponymics. It isn't meant to be comprehensive. In many countries other than those to which I have referred patronymics of different forms are widely used.

If your name isn't formed in this way it is probably formed from the name of a forebear's occupation, from a place with which they were somehow associated, or from the name of a patron. I shall describe these on another occasion.

Competing interests: None declared.

Provenance and peer review: not commissioned; not peer reviewed.

Aronson JKclinical pharmacologist. When I use a word. . . . St Bartholomew-onomastics and reputation. BMJ2022;376:0370. doi: 10.1136/bmj.o370 pmid: 35149550 